\title{
DOKUMEN ELEKTRONIK SEBAGAI ALAT BUKTI PADA PEMBUKTIAN DI PENGADILAN
}

\author{
Johan Wahyudi \\ Fakultas Hukum Universitas Airlangga Surabaya \\ e-mail: jo.fhua99@gmail.com
}

\begin{abstract}
ABSTRAK
Hubungan hukum yang terjalin di antara subjek hukum yang satu dengan yang lainnya dapat terjadi melalui perkembangan teknologi seperti media internet. Terutama dalam era globalisasi dewasa ini yang mana berbagai transaksi bisnis di antara para pengusaha itu terjadi pada domisili yang jauh berbeda, hal ini tentu saja membutuhkan metode yang dapat mempermudah para pihak untuk menuangkan kehendak dan mempercepat kehendak bisnis mereka. Kendala semacam itu teratasi dengan pemanfaatan fungsi internet yang mana dapat mempermudah para pengusaha dalam berkomunikasi dan bernegosiasi untuk mencapai kesepakatan yang nantinya akan melahirkan perjanjian. Namun terkadang tidak disadari oleh masyarakat jika terdapat berbagai resiko pernyalahgunaan atau kerentanan terhadap adanya perbuatan melawan hukum dalam penggunaan internet yang mana akan menimbulkan masalah hukum. Dalam hal ini Indonesia telah mengeluarkan aturan untuk menertibkannya yang mana tertuang dalam Undang-Undang No. 11 Tahun 2008 tentang Informasi dan Transaksi Elektronik.

Kata Kunci: dokumen elektronik, prinsip pembuktian, pengadilan.

ABSTRACT

The legal relationship between one law subject to other law subject could be rised through the technological developments, such as internet. Especially in today's globalization era where most business transactions will be done by businessman who live in a far different domicile, this situation obviously needs a method which could make the parties become easier to facilitate each other will and also make the whole business process become faster. This kind of problem solved by the existence of the internet. By using the function of the internet it could make the businessman become easier to communicate or negotiate to each other which will ended up with an obligatory agreement generated by the parties. However sometime people doesn't realize if there were such risks like abuse or unlawful act in using the internet which will raises legal issues. According to this situation Indonesia has generated rules to avoid the risk in a law form, which is law No. 11/2008 ITE.
\end{abstract}

Keywords: electronic documents, the evidence principle, the court.

\section{PENDAHULUAN}

Kemajuan peradaban manusia dan teknologi pada era globalisasi seperti sekarang ini berkembang begitu pesatnya, seiring dengan adanya kemajuan dalam penggunaan teknologi informasi yang begitu canggih. Perkembangan dan kemajuan teknologi informasi ditandai antara lain dengan maraknya penggunaan sarana teknologi interconnected network atau internet. Teknologi informasi diartikan sebagai suatu teknik untuk mengumpulkan, menyiapkan, menyimpan, memproses, mengumumkan, menganalisa, dan/atau menyebarkan informasi, sebagaimana ditentukan dalam Pasal 1 angka 3 Undang-Undang No. 11 Tahun 2008 tentang Informasi dan Transaksi Elektronik. Sedangkan istilah dari interconnected network atau internet itu sendiri mengandung beberapa pengertian yaitu: Internet merupakan suatu mekanisme hubungan antar jaringan pada komputer di seluruh dunia yang menggunakan basis Transmission Computer Protocol atau TCP dan Internet Protocol atau IP (Rahmi Jened, 2001:6); Internet ialah sebuah sarana alat penyebaran informasi secara global, sebuah media komputer tanpa terhalang batas geografis (Rieke Ustadianto, 2001:1); Internet adalah sebuah sistem komunikasi elektronik yang menciptakan suatu jaringan kerja komputer atau network dengan menyambung jaringan-jaringan komputer dan fasilitas komputer yang terorganisir di seluruh dunia (Kamus Online Merriem Websitester, www.m-w.com). 
Penggabungan antara teknologi komunikasi dan teknologi informatika memunculkan internet yang saat ini menjadi sarana utama pengembangan dari teknologi informasi. Keberadaan jaringan internet mengakibatkan tidak ada lagi jarak maupun batas antar negara, dalam rangka peningkatan efisiensi dalam transaksi perdagangan dengan menggunakan sistem elektronik, yang sering juga disebut dengan e-commerce.E-commerce itu sendiri mengandung arti secara umum dan luas yaitu penyebaran, pembelian, penjualan, pemasaran barang dan jasa melalui sistem elektronik seperti internet atau jaringan komputer lainnya. E-commerce dapat meliputi kegiatan-kegiatan seperti: transfer dana elektronik, pertukaran data elektronik, sistem manajemen inventori otomatis, dan suatu sistem pengumpulan data otomatis (http:// id.wikipedia.org/wiki/E-commerce). Keadaan yang demikian menunjukkan bahwa internet memberikan kemanfaatan bagi masyarakat, karena memberikan kemudahan-mudahan dalam melakukan berbagai aktifitas terutama yang terkait dengan pemanfaatan informasi, yaitu diantaranya salah satu manfaat yang paling dirasakan dengan adanya internet adalah bahwa sarana ini berfungsi sebagai media tanpa adanya suatu hambatan bagi pengiriman maupun penerimaan informasi.

Perkembangan dalam dunia maya yang seperti ini atau yang sering disebut dengan cyberspace (Agus Rahardjo, 2002:4), banyak menciptakan berbagai kemudahan, seperti dalam melakukan suatu transaksi, membantu dunia pendidikan, perdagangan, perbankan serta manfaat lain, baik yang bersifat ekonomi maupun sosial. Salah satu perubahan yang sangat besar akibat penggunaan teknologi informasi adalah dalam bidang sosialisasi dan transaksi elektronik. Perkembangan teknologi informasi secara signifikan telah mengubah sistem sosialisasi konvensional menjadi suatu sistem sosialisasi digital, begitu juga dengan transaksi yang dahulunya konvesional menjadi sistem digital seperti contohnya adalah penggunaan dari Mobile Banking maupun Internet Banking, yang merupakan sarana bertransaksi melalui internet, dan masih banyak lagi contoh-contoh lainnya.

Teknologi informasi dan media elektronik dinilai sebagai pelopor, yang akan mengintregasikan seluruh sistem dunia, baik dalam segi sosial, budaya, ekonomi dan keuangan (Dikdik M. Arief Mansur dan Elisatris Gultom, 2009:1). Penggabungan dari komputer dan telekomunikasi melahirkan sebuah fenomena yang mengubah cara masyarakat berkomunikasi secara konvensional yang pada akhirnya dapat merubah tatanan organisasi dan hubungan sosial masyarakat yang tidak dapat dihindari, karena fleksibilitas dan kemampuan telematika dengan cepat memasuki ke dalam berbagai sisi kehidupan masyarakat.

Perkembangan sebuah teknologi informasi ini harus diiringi dengan berkembangnya peraturanperaturan yang berlaku di masyarakat, sejalan dengan hal tersebut menurut Syamsul Muarif (Menunggu Lahirnya Cyber Law, http//www.cybernews.cbn.net. id), teknologi telah mengubah suatu pola kehidupan manusia di berbagai bidang, sehingga secara langsung telah mempengaruhi munculnya perbuatan hukum baru di suatu masyarakat. Bentuk-bentuk perbuatan hukum itu perlu juga mendapatkan penyesuaian, seperti melakukan harmonisasi terhadap perundangundangan yang sudah ada, mengganti jika sudah tidak sesuai lagi dan membentuk ketentuan yang baru.

Melalui sarana jaringan internet kita semua dapat mengakses apa saja yang dibutuhkan baik dalam informasi, transaksi, sosialisasi dan banyak lagi hal lainnya. Akan tetapi dengan semakin mudahnya akses dalam media internet maka memungkinkan semakin mudah pula terjadi tindakan-tindakan yang melanggar hukum yang dilakukan, seperti pencemaran nama baik, transaksi bisnis yang didalamnya mengandung unsur penipuan maupun banyaknya transaksi yang tidak diikuti adanya pelaksanaan prestasi dari salah satu pihak (wanprestasi), dan lain sebagainya.

Perkembangan teknologi dapat meningkatkan tindakan pelanggaran norma-norma keperdataan, baik itu pelanggaran norma kontrak (wanprestasi) maupun pelanggaran norma hukum atau perbuatan melanggar hukum, maka sudah seharusnya peraturan juga ditingkatkan sesuai dengan berkembangnya kemajuan teknologi yang ada, terutama dalam hal pengajuan alat bukti yang digunakan sebagai sarana pembuktian di pengadilan. Sehingga, terkait dengan hukum pembuktian biasanya akan memunculkan sebuah posisi dilema, di salah satu sisi diharapkan agar hukum dapat mengikuti perkembangan zaman dan teknologi, di sisi yang lain perlu juga pengakuan hukum terhadap berbagai jenis-jenis perkembangan teknologi digital untuk berfungsi sebagai alat bukti di pengadilan (Munir Fuady, 2001:151).

Pembuktian dan alat bukti di dalam hukum acara perdata, merupakan hal yang sangat penting dalam rangka mencari suatu kebenaran dan kepastian hukum atas suatu perkara yang diajukan oleh penggugat, sehingga jika suatu alat bukti tidak dapat ditemukan dan/atau tidak diketemukannya aturan hukum yang mengatur, maka aparat penegak hukum akan kesulitan dalam menegakkan hak-hak keperdataan bagi para pihak. Disahkannya Undang-Undang No. 11 Tahun 
2008 tentang Informasi dan Transaksi Elektronik (yang selanjutnya dapat disebut UU ITE) diharapkan dapat memberikan manfaat yang berguna bagi aparat penegak hukum, serta sekaligus untuk mencegah tindakan-tindakan yang melanggar hukum yang dapat dilakukan melalui sarana internet.

Lebih lanjut, adanya UU ITE diharapkan dapat memberantas suatu tindakan-tindakan yang melawan hukum di bidang informasi dan teknologi. Namun demikian, pada kenyataannya sejak UU ITE disahkan sudah banyak masyarakat yang menanyakan tentang isi muatan akan UU ITE ini, hal tersebut dikarenakan salah satu dari pasalnya dianggap membatasi para pengguna internet untuk dapat mengemukakan suatu pendapatnya, yang salah satunya adalah para blogger (Enda Nasution, http://blog.kenz.or.id/2006/02/09/ definisi-blog-menurut-orang-indonesia.html) yang merasa ada suatu pembatasan dalam mencurahkan pendapat dan kritikan terhadap suatu kejadian yang ada.

Dalam dunia intenet juga dikenal istilah e-mail, yaitu, surat elektronik atau surat digital atau pos elektronik. E-mail adalah sebuah sarana berkirim surat melalui jalur internet. Melalui surat biasa (secara manual) umumnya pengirim surat memerlukan biaya untuk membeli perangko dan juga waktu yang lebih lama untuk pengirimannya, akan tetapi melalui surat elektronik biaya yang dikeluarkan adalah biaya untuk membayar sambungan internet serta waktu yang diperlukan untuk pengirimannya relatif singkat dan cepat (secara online).

Berbagai aktifitas dan kegiatan dapat dilakukan dengan cara menggunakan sarana teknologi internet, semisal e-mail yang seringkali menimbulkan suatu permasalahan hukum, seperti contohnya, kasus yang menimpa Prita Mulyasari yang dijerat dengan Pasal 27 ayat 3 UU ITE.

Kejadian-kejadian tersebut timbul atas tindakan Prita Mulyasari yang mengirimkan sebuah e-mail ke sahabatnya yang berisikan suatu curahan hati atas ketidakpuasan terhadap pelayanan RS. Omni, maka RS. Omni menggugat Prita Mulyasari baik secara hukum pidana maupun hukum perdata. Dalam tuntutan pidana, jaksa menjerat dengan pasal berlapis, yaitu pada Pasal 310 Kitab Undang-Undang Hukum Pidana (yang selanjutnya disebut KUHP) tentang pencemaran nama baik dengan ancaman hukuman 1,4 tahun atau 16 bulan penjara, Pasal 311 KUHP tentang pencemaran nama baik secara tertulis dengan ancaman 4 tahun penjara, dan Pasal 27 Ayat 3 UU ITE dengan ancaman 6 tahun penjara dan denda Rp1 miliar (http://babasz-freedom.blogspot.com/2009/06/ kasus-prita-mulyasari-dengan-rs-omni.html, diakses pada tanggal 06 Oktober 2009).

Selanjutnya pada tanggal 11 Mei 2009 Pengadilan Negeri Tangerang memenangkan gugatan atas RS. Omni. Putusan perdata menyatakan Prita Mulyasari terbukti telah melakukan suatu perbuatan melawan hukum yang merugikan RS. Omni. Bahwa hakim memutuskan Prita Mulyasari membayar kerugian materiil sebesar Rp161 juta sebagai pengganti uang klarifikasi di koran nasional dan Rp100 juta untuk kerugian immateriil (http://babasz-freedom.blogspot. com/2009/06/kasus-prita-mulyasari-dengan-rs-omni. html, diakses pada tanggal 06 Oktober 2009).

Dari kasus Prita tersebut yang perlu mendapatkan pemahaman yang benar adalah tentang alat-alat bukti yang dapat digunakan dalam proses pembuktian yang digunakan oleh penggugat, dan pertimbangan hakim atas alat bukti yang dijadikan dasar dalam memutus perkara Prita Mulyasari, hal tersebut dikarenakan masih banyak perbedaan pendapat yang disampaikan oleh para ahli hukum tentang keabsahan alat bukti elektronik itu sendiri. Hal-hal tersebut dikarenakan alat bukti elektronik merupakan hal yang baru di masyarakat sehingga banyak pendapat yang berbeda dalam menyingkapi keberadaan bukti elektronik.

Perkembangan selanjutnya, banyak bermunculan kasus-kasus yang baru di beberapa daerah di wilayah Jawa Timur khususnya, yang berawal dari adanya suatu ketidakpahaman atas suatu akibat hukum yang ditimbulkan dengan menggunakan sarana teknologi internet tersebut. Kebanyakan dari kasus tersebut banyak menimpa anak-anak sekolah yang memang seringkali menggunakan sarana internet sebagai media komunikasi di antara mereka. Bahkan tidak jarang pula media teknologi internet digunakan sebagai sarana bagi orang-orang yang mempunyai tujuan tidak baik untuk mengelabui, memperdaya bahkan mencemarkan nama baik seseorang, yang pada akhir kesemuanya itu membawa kepada pelaku ke muka pengadilan, seperti contohnya yang baru saja terjadi di PN Surabaya, dimana seseorang telah dijatuhi hukuman pidana dikarenakan orang tersebut telah didakwa membobol sebuah blogger di internet milik orang lain.

Perlu dipahami bahwa perkembangan penggunaan alat elektronik dalam berbagai transaksi terutama dalam bersosialisasi memiliki keuntungan antara lain efisiensi, kecepatan dan kemudahan dalam melakukan kegiatan. Selain dari keuntungan tersebut, dalam penggunaan alat elektronik terdapat pula kekurangan atau kelemahannya apabila dihadapkan pada masalah alat bukti di pengadilan. Dengan perkataan lain, bahwa 
perkembangan teknologi sangat besar pengaruhnya terhadap pergeseran pola hidup suatu masyarakat, sedangkan pergeseran pola hidup sebagai suatu akibat pengaruh perkembangan teknologi menimbulkan dampak-dampak positif dengan segala manfaatnya bagi masyarakat sekaligus menimbulkan dampak negatif, yang pada akhirnya dapat pula menimbulkan kerugian baik secara materiil maupun immateriil.

Berdasarkan uraian-uraian sebagaimana terurai di atas, maka permasalahan hukum yang akan diteliti dalam penelitian ini adalah: Bagaimanakah prinsip pembuktian setelah berlakunya UU ITE; Bagaimana keabsahan dan kekuatan pembuktian atas dokumen elektronik sebagai alat bukti di pengadilan setelah berlakunya UU ITE.

\section{PEMBAHASAN}

\section{Prinsip Pembuktian dan Pengaturannya di dalam UU ITE}

Pembuktian merupakan tahap yang menentukan dalam proses perkara, karena dari hasil pembuktian dapat diketahui benar atau tidaknya suatu gugatan atau bantahan tersebut. Hal itu berarti, bahwa apabila penggugat dapat membuktikan dalil-dalilnya dalam gugatannya maka hakim akan mengabulkan gugatan dari penggugat, sedangkan apabila Penggugat tidak dapat membuktikan dalil-dalil dalam gugatannya atau tergugat dapat membuktikan dalil-dalil bantahannya dalam jawabannya atau dupliknya maka Hakim akan menolak gugatan dari Penggugat. Dalam tahapan pembuktian terdapat 2 (dua) unsur yang memegang peranan penting, yaitu:

Pertama, Unsur-unsur alat bukti. Para pihak dalam tahapan pembuktian harus menggunakan alat bukti yang sah menurut hukum pembuktian, dan tidak boleh menggunakan alat bukti yang tidak diatur dalam peraturan perundangan. Berkenaan dengan macam alat bukti yang sah, menurut pasal 164 HIR jo. Pasal 1866 BW ada 5 macam alat bukti: bukti tulisan/surat; bukti saksi; bukti persangkaan; bukti pengakuan; dan, bukti sumpah. Kedua, Peraturan pembuktian. Bahwa kelima macam alat bukti di atas dianggap sebagai alat bukti yang sah dan dapat dipergunakan sebagai alat bukti di persidangan, hal tersebut dikarenakan di dalam peraturan perundang-undangan (HIR/Rbg dan HIR) mengatur cara pembuatan, penggunaan dan kekuatan pembuktiannya sebagai alat bukti.

Makna pembuktian dalam persidangan adalah memberikan dasar-dasar yang sah atas suatu gugatan atau bantahan, sebagaimana ditentukan dalam asas pembuktian dalam hukum acara perdata, yang diatur di dalam Pasal 163 HIR jo. 1865 BW. Disamping itu pembuktian harus dilakukan dengan menggunakan alat-alat bukti yang sah. Adapun alat-alat bukti dalam hukum acara perdata dan alat-alat bukti dalam hukum acara pidana, adalah sebagai berikut:

\begin{tabular}{ll}
\hline \multicolumn{1}{c}{ ALAT BUKTI } & \multicolumn{1}{c}{ ALAT BUKTI } \\
HUKUM ACARA PERDATA & HUKUM ACARA PIDANA \\
\hline Pasal 164 HIR jo. 1866 BW & \multicolumn{1}{c}{ Pasal 141 KUHAP } \\
1. Tulisan atau Surat & 1. Keterangan Saksi \\
2. Saksi-saksi & 2. Keterangan Ahli \\
3. Persangkaan & 3. Surat \\
4. Pengakuan & 4. Petunjuk \\
5. Sumpah & 5. Keterangan Terdakwa \\
\hline
\end{tabular}

Berdasarkan pengaturan macam-macam alat bukti di atas, maka dapat dikatakan bahwa urutan-urutan penyebutan alat bukti di dalam hukum acara pidana berbeda dengan pengaturan macam alat bukti di dalam hukum acara perdata. Di dalam hukum acara pidana, pembuktian lebih diutamakan dengan menggunakan alat bukti berupa saksi, hal ini bermakna bahwa suatu perbuatan pidana menurut pembentuk undang-undang hanya dapat diketahui oleh seorang saksi yang secara langsung mengetahui atas perbuatan pidana tersebut. Sedangkan di dalam hukum acara perdata, pembuktian lebih diutamakan dengan menggunakan alat bukti tulisan atau surat, hal ini bermakna bahwa suatu hubungan hukum keperdataan menurut pembentuk undang-undang dapat dipersiapkan terlebih dahulu oleh para pihak dengan membuat suatu perjanjian dalam bentuk tulisan atau surat.

Selanjutnya perlu dipahami bahwa dalam rangka penilaian keabsahan penggunaan alat bukti di dalam hukum acara pidana, terdapat prinsip yang sama baik di dalam Pasal 294 ayat 1 HIR dan Pasal 183 KUHAP, yang pada asasnya mengatur tentang:

"Hakim tidak boleh menjatuhkan pidana kepada seseorang kecuali apabila dengan sekurang-kurangnya dua alat bukti yang sah ia memperoleh keyakinan bahwa sesuatu tindak pidana benar-benar terjadi dan bahwa terdakwalah yang bersalah melakukanya"

Sedangkan, di dalam hukum acara perdata dalam rangka penilaian keabsahan penggunaan alat bukti tidak terdapat ketentuan semacam di atas, dan hanya mengenal prinsip pembuktian sebagaimana ditentukan dalam pasal 163 HIR jo. 1865 BW yang menyatakan bahwa:

"Barangsiapa menyatakan mempunyai hak atas suatu barang, atau menunjuk suatu peristiwa untuk meneguhkan haknya, ataupun menyangkal hak orang lain, maka orang itu harus membuktikannya"

Dengan demikian, berdasarkan rumusan Pasal 163 HIR jo. 1865 BW tersebut, maka keduabelah pihak baik itu penggugat maupun tergugat dapat dibebani dengan beban pembuktian oleh hakim. Hal tersebut bermakna bahwa hakim wajib memberikan beban 
pembuktian kepada penggugat untuk membuktikan dalil atau peristiwa yang dapat mendukung dalil tersebut, yang diajukan oleh penggugat, sedangkan bagi tergugat, hakim wajib memberikan suatu beban pembuktian untuk membuktikan bantahannya atas dalil yang diajukan oleh para penggugat. Penggugat tidak diwajibkan membuktikan kebenaran bantahan tergugat, demikian pula sebaliknya tergugat tidak diwajibkan untuk membuktikan kebenaran peristiwa yang diajukan oleh penggugat. Dengan demikian, jika penggugat tidak bisa membuktikan dalil atau peristiwa yang diajukannya, ia harus dikalahkan, sedangkan jika tergugat tidak dapat membuktikan bantahannya, ia harus dikalahkan (Sudikno Mertokusumo, 1998:114). Namun demikian, hakim hendaknya tidak begitu saja secara harfiah melaksanakan asas pembuktian, tetapi hakim harus bijaksana dan pantas, yaitu hendaknya hakim meletakkan keharusan membuktikan kepada pihak yang paling gampang untuk membuktikan, dan tidak membebani kepada pihak yang paling sulit untuk membuktikan, terkhusus pada perkara yang didasarkan pada suatu hubungan hukum yang timbul tanpa adanya alat bukti tulisan atau surat (dilakukan secara lisan) oleh para pihak.

Hakim dalam rangka memberikan suatu beban pembuktian, dalam beberapa peristiwa khusus, telah diatur di dalam BW tentang beban pembuktiannya, yaitu misalnya: 1 . Adanya keadaan memaksa dalam suatu perikatan (hubungan hukum) harus dibuktikan oleh debitur, sebagaimana ditentukan dalam Pasal 1244 BW. 2. Barangsiapa menguasai barang bergerak, dianggap sebagai pemilik, sebagaimana ditentukan pada Pasal 1977 ayat 1 BW. Sehingga, apabila pihak lawan mendalilkan sebaliknya, maka pihak lawan tersebut harus membuktikan dalilnya. 3. Peristiwa notoir atau yang umum diketahui, tidak perlu pula dibuktikan misalnya: a. peristiwa bencana alam yang telah diberitakan secara luas; b. peristiwa yang oleh masyarakat umum telah diketahui; c. peristiwa yang terjadi di dalam persidangan. 4. Keseluruhan dalil yang telah diakui secara penuh atau bulat di dalam persidangan tidak perlu dibuktikan lagi.

Sebagaimana dikemukakan di atas, bahwa alat bukti yang paling diutamakan dalam hukum acara perdata adalah alat bukti tulisan atau surat, yang dibedakan menjadi dua yaitu: 1 . Akte yang dibedakan menjadi 2 (dua) yaitu: Akte otentik; dan Akte di bawah tangan; dan 2. Surat atau tulisan lain.

Yang dimaksud dengan akte ialah tulisan yang dengan sengaja dibuat untuk dijadikan alat bukti adanya hubungan hukum dan ditandatangani. Dengan demikian unsur-unsur dalam pembuatan akte meliputi:
Tulisan; Dengan sengaja dibuat; Untuk alat bukti; Adanya hubungan hukum; Ditandatangani.

Dari kelima unsur-unsur dalam pembuatan akte itu, unsur yang paling penting terkait dengan pembuktian adalah tanda tangan, yang dalam asas-asas hukum dinyatakan bahwa barangsiapa yang menandatangani suatu surat dianggap telah mengetahui isinya dan bertanggungjawab. Adapun syarat penandatanganan dalam pembuatan akte diatur di dalam Pasal 1874 BW atau Pasal 1 Stbl 1867 No. 29.

Terkait dengan pembuatan dan penggunaan akte sebagai alat bukti di Pengadilan, maka perlu dipahami adanya beberapa pengaturan yaitu sebagai berikut: Pertama, Pasal 1867 BW yang menentukan bahwa pembuktian dengan tulisan dilakukan dengan tulisan otentik maupun dengan tulisan di bawah tangan. Kedua, Pasal 1868 BW yang menentukan bahwa suatu akta otentik ialah suatu akte yang di dalam bentuk yang ditentukan oleh undang-undang, dibuat oleh atau di hadapan pegawai-pegawai umum yang berkuasa untuk itu di tempat dimana akte dibuatnya. Ketiga, Pasal 1869 BW yang menentukan bahwa suatu akta yang karena tidak berkuasa atau tidak cakapnya pegawai termaksud di atas, atau karena suatu cacat dalam bentuknya, tidak dapat diperlakukan sebagai akta otentik, namun mempunyai kekuatan pembuktian sebagai tulisan di bawah tangan jika ditandatangani oleh para pihak. Keempat, Pasal 1877 BW, yang menentukan bahwa jika suatu akta otentik, yang berupa apa saja, dipersangkakan palsu, maka dapat ditangguhkan menurut ketentuan-ketentuan Reglement Acara Perdata.

Selanjutnya, terkait dengan pengunaan alat bukti akte di bawah tangan, maka ditentukan bahwa suatu tulisan di bawah tangan yang telah diakui oleh orang terhadap siapa tulisan itu hendak dipakai, atau yang dengan cara menurut undang-undang dapat dianggap sebagai diakui, memberikan terhadap orang-orang yang menandatanganinya serta para ahli warisnya dan orang-orang yang mendapat hak daripada mereka, bukti yang sempurna seperti suatu akta otentik, dan demikian pula berlakulah ketentuan Pasal 1871 BW untuk tulisan itu (penuturannya harus berhubungan langsung dengan pokok isi akta, jika tidak hanya jadi bukti permulaan) (vide pasal $1875 \mathrm{BW}$ ) (Edmon Makarim, 2012:8). Selanjutnya, di dalam Pasal 1877 BW juga ditentukan pula bahwa jika seseorang yang memungkiri tulisan atau tandatangannya atau pun jika para ahli warisnya atau orang-orang yang mendapat hak daripadanya menerangkan tidak mengakuinya, maka hakim harus memerintahkan supaya kebenaran dari pada tulisan atau tanda-tangan tersebut diperiksa 
dihadapan pengadilan (Edmon Makarim, 2012:8). Adanya peraturan yang demikian sangat diperlukan guna dapat menyingkapi maraknya berbagai macam transaksi elektronik di masyarakat, yang seringkali dipersamakan dengan suatu pembuatan bentuk akte di bawah tangan.

Berdasarkan ketentuan pada Pasal 1 angka 2 UU ITE, yang dimaksud dengan transaksi elektronik adalah suatu perbuatan hukum yang dilakukan dan menggunakan komputer dan/atau media elektronik lainnya. Dalam rangka melakukan transaksi elektronik tersebut, maka para pihak akan selalu menggunakan suatu dokumen elektronik sebagai landasan bagi mereka untuk melakukan hubungan hukum. Terkait dengan adanya transaksi elektronik yang di dalamnya menggunakan dokumen elektronik, di dalam UU ITE terdapat suatu prinsip yang menentukan bahwa setiap orang yang menyatakan hak, memperkuat hak yang telah ada, atau menolak hak orang lain (Prinsip yang sama ada di dalam Pasal 163 HIR jo. 1865 BW) berdasarkan adanya informasi elektronik dan/ atau dokumen elektronik harus memastikan bahwa informasi elektronik dan/atau dokumen elektronik yang ada padanya berasal dari sistem elektronik yang memenuhi syarat berdasarkan peraturan perundangundangan.

Adapun persyaratan yang ditentukan di dalam UU ITE adalah bahwa syarat-syarat adanya transaksi elektronik dan/atau dokumen elektronik adalah baik subyek dan sistemnya sudah harus bersertifikasi yang dilakukan oleh (Minanoer Rachman, 2012:10): Pertama, Lembaga Sertifikasi Keandalan, yang akan melakukan fungsi administrasi yaitu dapat mencakup: Registrasi; Otentikasi fisik terhadap pelaku usaha; Pembuatan dan pengelolaan sertifikat keandalan; serta Membuat daftar sertifikat yang telah dibekukan. Sebagaimana ditentukan dalam Pasal 10 UU ITE. Kedua, Penyelenggara Sertifikasi Elektronik, yang melakukan fungsi administrasi yaitu dapat mencakup: Registrasi; Otentikasi fisik terhadap si pemohon; Pembuatan dan pengelolaan kunci publik maupun kunci privat; Pengelolaan sertifikat elektronik; serta Daftar sertifikat yang telah dibekukan. Sebagaimana ditentukan dalam Pasal 13 dan Pasal 14 UU ITE.

\section{Keabsahan dan Kekuatan Pembuktian Dokumen Elektronik Berdasarkan UU ITE}

Dengan diberlakukannya UU ITE maka terdapat suatu pengaturan yang baru mengenai alat-alat bukti dokumen elektronik. Berdasarkan ketentuan Pasal 5 ayat 1 UU ITE ditentukan bahwa informasi elektronik dan/atau dokumen elektronik dan/atau hasil cetaknya merupakan alat bukti hukum yang sah. Selanjutnya di dalam Pasal 5 ayat 2 UU ITE ditentukan bahwa informasi elektronik atau dokumen elektronik dan/ atau hasil cetaknya sebagaimana dimaksud pada ayat 1 merupakan perluasan alat bukti yang sah dan sesuai dengan hukum acara yang berlaku di Indonesia. Dengan demikian, bahwa UU ITE telah menentukan bahwa dokumen elektronik dan/atau hasil cetaknya merupakan suatu alat bukti yang sah dan merupakan perluasan alat bukti yang sah sesuai dengan hukum acara yang telah berlaku di Indonesia, sehingga dapat digunakan sebagai alat bukti di muka persidangan.

Selanjutnya, berdasarkan ketentuan Pasal 5 ayat 3 UU ITE ditentukan bahwa informasi elektronik dan/atau dokumen elektronik dinyatakan sah apabila menggunakan suatu sistem elektronik sesuai dengan ketentuan-ketentuan yang ada di dalam UU ITE. Dengan demikian penggunaan dokumen elektronik sebagai suatu alat bukti yang dianggap sah apabila menggunakan suatu sistem elektronik sesuai dengan ketentuan sebagaimana diatur dalam Pasal 6 UU ITE, yang menentukan bahwa dokumen elektronik dianggap sah sepanjang informasi yang tercantum di dalamnya dapat diakses, ditampilkan, dijamin keutuhannya, dan dapat dipertanggungjawabkan, sehingga menerangkan suatu keadaan. Di samping itu, dokumen elektronik yang kedudukannya dapat disetarakan dengan dokumen yang dibuat di atas kertas, sebagaimana ditentukan dalam Penjelasan Umum UU ITE.

Ketentuan tersebut dikecualikan, sebagaimana termaksud di dalam Pasal 5 ayat 4 UU ITE, yang menentukan bahwa ada beberapa jenis dokumen elektronik yang tidak dapat dijadikan alat bukti yang sah apabila terkait dengan pembuatan: Surat yang menurut undang-undang harus dibuat dalam bentuk tertulis; dan Surat beserta dokumennya yang menurut undang-undang harus dibuat dalam suatu bentuk akta notariil atau akta yang dibuat oleh pejabat pembuat akta.

Berdasarkan ketentuan Pasal 5 ayat 4 UU ITE tersebut, maka apabila para pihak hendak membuat suatu perjanjian yang bersifat formil dianggap belum sah apabila belum dituangkan dalam bentuk tertulis secara manual, baik dalam bentuk akte di bawah tangan maupun akte otentik. Adapun contoh perjanjian yang bersifat formil diantaranya adalah: Perjanjian Perdamaian, vide Pasal 1851 BW; Perjanjian Hibah, vide Pasal $1682 \mathrm{BW}$; serta, Perjanjian jual-beli dengan obyek tanah, semisal, Akta jual-beli sebidang tanah, vide Peraturan Pemerintah No. 24 Tahun 1997 tentang Pendaftaran Tanah. 
Dalam rangka pembuatan suatu perjanjian atau transaksi elektronik yang dituangkan dalam bentuk dokumen elektronik, maka keabsahan suatu dokumen elektronik tersebut di dalamnya juga harus memuat sebuah tanda-tangan dalam bentuk elektronik, hal ini sesuai dengan pengaturan tentang unsur-unsur terpenting dalam pembuatan akte, yang diatur di dalam Pasal 1867 BW jo. Pasal 1874 BW, dan syarat sahnya perjanjian yang diatur di dalam Pasal 1320 BW. Selanjutnya, ditentukan bahwa sebuah Tanda Tangan Elektronik memiliki kekuatan hukum dan akibat hukum yang sah selama memenuhi persyaratan sebagaimana ditentukan dalam Pasal 11 UU ITE, yaitu: a. data pembuatan Tanda Tangan Elektronik terkait hanya kepada para Penanda Tangan; $b$. data pada pembuatan Tanda Tangan Elektronik pada saat proses penandatanganan elektronik hanya berada dalam kuasa Penanda Tangan; c. segala perubahan terhadap Tanda Tangan Elektronik yang terjadi setelah waktu penandatanganan dapat diketahui; d. segala perubahan terhadap Informasi Elektronik yang terkait dengan Tanda Tangan Elektronik tersebut setelah waktu penandatanganan dapat diketahui; e. terdapat cara tertentu yang dipakai untuk mengidentifikasi siapa Penandatangannya; f. terdapat cara tertentu untuk menunjukkan bahwa Penanda Tangan telah memberikan suatu persetujuan terhadap informasi elektronik yang terkait.
Selanjutnya, ditentukan dalam Pasal 12 ayat 2 UU ITE bahwa setiap orang yang terlibat dalam Tanda Tangan Elektronik berkewajiban memberikan pengamanan atas Tanda Tangan Elektronik yang digunakan.

Adanya suatu penandatanganan secara elektronik tersebut terkait dengan persyaratan secara umum keotentikan suatu alat bukti, yaitu (Edmond Makarim, 2012:10): Pertama, Keotentikan secara materiil yaitu: Kejelasan syarat subyektif dan obyektif, terkhusus, kecakapan bersikap tindak; Jelas waktu dan tempat; Confidentiality; Dapat ditelusuri kembali; Terjamin Keutuhan data atau Keamanan informasi; Aslinya harus sesuai atau sama dengan copynya, yaitu salinan akta dan/atau kutipan akta. Kedua, Keotentikan secara formil yaitu: Sesuai bentuk yang ditentukan oleh undang-undang, termasuk media dan format tertentu; Pembacaan, yaitu apakah yang menjadi bukti telah dilakukannya suatu pembacaaan; Pencantuman waktu, yaitu apakah jaminan waktu telah dituliskan dengan benar (time-stamping); Keamanan dokumen beserta subtansinya, yaitu apakah historical data terhadap dokumen akta sudah jelas; Pemeliharaan Log atau journal-notaris (protokol notaris), yaitu apakah benar telah terpelihara dengan baik.

Pemahaman atas perbedaan keotentikan alat bukti secara konvensional dengan secara elektronik yaitu (Edmon Makarim, 2012:9):

\begin{tabular}{|c|c|}
\hline Paperbased & Electronic-based \\
\hline $\begin{array}{l}\text { Pemahaman Umum: } \\
\text { (functional equivalent approach) } \\
\text { * Tertulis; } \\
\text { * Bertandatangan; } \\
\text { * Asli (original). }\end{array}$ & $\begin{array}{l}\text { * Apa yang telah dituliskan atau disimpan dapat ditemukan } \\
\text { kembali. } \\
\text { * Terdapat informasi yang menemukan subyek hukum yang } \\
\text { bertanggungjawab. } \\
\text { * Apa yang tersimpan dan ditemukan tidak ada perubahan } \\
\text { (terjamin keutuhannya). }\end{array}$ \\
\hline $\begin{array}{l}\text { Bermeterai cukup (sebenarnya apakah menjalankan fungsi } \\
\text { budgeter atau pembuktian?) }\end{array}$ & $\begin{array}{l}\text { Sebenarnya dapat dilakukan dengan e-registry dan e-filing yang } \\
\text { baik, namun apakah sesuai dengan efisiensi dalam transaksi? }\end{array}$ \\
\hline $\begin{array}{l}\text { * kehadiran fisik pihak secara langsung penghadap dengan } \\
\text { notaris (Pasal } 16 \text { ayat } 1 \text { huruf } 1 \text { ). } \\
\text { * pembacaan akta di hadapan para pihak dan para pihak mengerti, } \\
\text { kecuali bila para pihak tidak minta untuk dibacakan (Pasal } \\
16 \text { ayat } 7 \text { ). } \\
\text { * kehadiran dan tandatangan dari para saksi-saksi yang tidak } \\
\text { mempunyai hubungan darah atau perkawinan, kecuali bila } \\
\text { ditentukan lain oleh undang-undang (Pasal } 39 \text { dan } 40 \text { ). } \\
\text { * paraf para pihak, saksi dan notaris pada setiap halaman sebagai } \\
\text { tindakan persetujuan. }\end{array}$ & $\begin{array}{l}\text { * Rekaman elektronik (video) + penelusuran eID } \\
\text { * Penjelasan Pasal } 16 \text { ayat } 1 \text { huruf } 1 \text {--> kehadiran fisik --> } \\
\text { apakah kehadiran secara elektronik bukan kehadiran secara } \\
\text { fisik? } \\
\text { * Fasilitas mobile } 3 \mathrm{G} \text { telah memungkinkan pembuktian apakah } \\
\text { orang tersebut benar-benar pada suatu wilayah tertentu. } \\
\text { * Time-stamping membuktikan logisnya jumlah akta? }\end{array}$ \\
\hline
\end{tabular}

Berkenaan dengan keotentikan suatu tandatangan elektronik, maka dapat diperbedakan sesuai dengan faktanya sebagai berikut (Edmon Makarim, 2012:2224): Pertama, Jika tandatangan elektronik belum terpercaya, namun para pihak telah sepakat untuk mengakui, maka dapat langsung diakui keasliannya tanpa harus dibuktikan; Kedua, Jika tandatangan elektronik belum dapat terpercaya dan ada salah satu pihak yang tidak mengakui, maka pengadilan harus dapat membuktikan bahwa tidak ada pemalsuan atau kesalahan sistem, sehingga hakim memerintahkan pemeriksaan kebenaran dengan menggunakan seorang 
ahli forensik, untuk mengetahui apakah telah terjadi pemalsuan atau kesalahan sistem (Pasal 1877 BW); Ketiga, Jika tandatangan elektronik terpercaya dan telah terakreditasi dan para pihak mengakui, maka dapat langsung diakui suatu keasliannya tanpa harus dibuktikan; Keempat, Jika tandatangan elektronik telah terakreditasi dan ada salah satu pihak yang tidak mengakui, maka pihak yang tidak mengakui harus dapat membuktikan bahwa telah ada pemalsuan atau kesalahan prosedur.

Di dalam praktek peradilan, sikap hakim dalam memandang suatu alat bukti dokumen elektronik dapat beragam, yaitu (Minanoer Rachman, 2012:17): Ada yang berpendapat, bahwa alat bukti dokumen elektronik sebagai alat bukti sah sebagai tambahan alat bukti konvensional dalam Hukum Acara; Namun ada juga yang berpendapat, bahwa dokumen elektronik sebagai alat bukti pendamping yang harus didukung dengan alat bukti lain untuk menambah keyakinan hakim.

Sehingga, apabila berpatokan pada pendapat yang pertama, maka dokumen elektronik dapat disamakan dengan alat bukti akte di bawah tangan, dimana akte di bawah tangan yang diakui oleh para pihak mempunyai kekuatan pembuktian formal dan materiil, sedangkan pembuktian keluar tidak memiliki kecuali akte di bawah tangan yang didaftarkan pada seorang pegawai umum. Adapun yang dimaksud dengan mempunyai kekuatan pembuktian: Formal, yaitu apa yang tertuang ke dalam akte memang diucapkan oleh para pihak; Materiil, yaitu apa yang diucapkan para pihak sesuai dengan keadaan sebenarnya.

Namun demikian, dalam praktek di lingkungan Pengadilan Negeri Surabaya, ada beberapa hakim yang berpendapat bahwa dokumen elektronik dapat dipersamakan dengan alat bukti surat, dan apabila dokumen elektronik tersebut, misalnya dalam bentuk Facebook, yang kemudian dapat di download dan dicetak (print-out). Namun, dapat juga dokumen elektronik dapat dipersamakan dengan persangkaan, apabila dokumen elektronik tersebut, misalnya dalam bentuk e-mail yang diterima, yang sebelumnya sudah didukung oleh 2 (dua) alat bukti yang lain.

Pendapat tersebut telah dituangkan dalam suatu putusan yang pernah dijatuhkan oleh Hakim yang telah bersangkutan atas suatu perkara perselingkuhan dengan menggunakan suatu alat bukti berupa Short Message Service atau SMS, yang kemudian SMS tersebut ditransformasikan menjadi sebuah printout, yang pada akhirnya dianggap sebagai alat bukti surat. Demikian juga dalam perkara yang lain, kita seorang suami memergoki istrinya sedang berkirim e-mail dengan pria lain yang isinya tidak semestinya, yang kemudian oleh hakim e-mail tersebut dianggap sebagai alat bukti persangkaan.

Di samping itu, ada suatu perkara di Pengadilan Hubungan Industrial Surabaya, dengan nomer Reg. 28/G/2010/PHI.Sby, yang pada perkara tersebut salah satunya menggunakan alat bukti dokumen elektronik yang berupa pemberitaan di Metrotvnews.com, yang pada konsiderannya hakim menilai alat bukti dokumen elektronik tersebut sebagai suatu persangkaan, dimana kekuatan pembuktiannya masih harus didukung oleh 2 (dua) orang saksi yang secara langsung melihat kejadian-kejadian yang sama dengan kejadian pada pemberitaan di Metrotvnews.com tersebut.

Sedangkan di Pengadilan Negeri Sidoarjo, ada beberapa hakim yang berpendapat bahwa alat bukti dokumen elektronik tetap dikategorikan dalam alat bukti surat, serta kedudukan alat bukti dokumen elektronik dalam suatu persidangan perkara perdata tidak dapat berdiri sendiri, melainkan harus didukung oleh alat bukti yang lain. Pada prinsipnya, sepanjang ada hubungan dengan alat bukti lain yang mendukung maka layak digunakan, serta dalam memeriksa alat bukti dokumen elektronik bisa menggunakan saksi ahli (Bukaeri dan Saryana). Namun, dalam praktek di Pengadilan Negeri Sidoarjo, beberapa majelis hakim menyatakan bahwa belum ada satu pun perkara yang disidangkan dengan menggunakan alat bukti dokumen elektronik.

Dalam rangka penggunaan dokumen elektronik, maka yang perlu dipahami adalah bahwa UU ITE melarang perbuatan-perbuatan sebagaimana diatur dalam ketentuan Pasal 27 sampai dengan Pasal 37, yang menentukan bahwa jika terjadi penyalahgunaan dalam penggunaan teknologi informasi, terkhusus dokumen elektronik, yang merugikan bagi pihak lain, dapat digugat atau dituntut baik secara keperdataan maupun kepidanaan, sebagaimana ditentukan dalam Pasal 38, Pasal 39, serta Pasal 45 sampai dengan Pasal 52 UU ITE.

\section{PENUTUP \\ Kesimpulan}

Berdasarkan keseluruhan uraian-uraian tersebut di atas, maka dapat ditarik suatu kesimpulan sebagai berikut: Pertama, Bahwa pengaturan tentang prinsip pembuktian yang terdapat di dalam Pasal 163 HIR jo. Pasal 1865 BW yang menentukan bahwa barangsiapa menyatakan telah mempunyai hak atas suatu barang, atau menunjuk suatu peristiwa untuk meneguhkan haknya, ataupun menyangkal hak orang lain, maka orang itu harus membuktikannya, nampaknya masih 
tetap diberlakukan dan tidak mengalami perubahan setelah diberlakukannya UU ITE, hanya saja diberi penekanan bahwa para pihak harus sudah memastikan bahwa dokumen elektronik yang telah ada padanya berasal dari sistem elektronik yang memenuhi syarat berdasarkan peraturan perundang-undangan.

Kedua, Bahwa setelah diberlakukannya UU ITE terdapat penambahan macam alat bukti, dan diakuinya dokumen elektronik sebagai alat bukti yang sah, sebagaimana ditentukan dalam Pasal 5 ayat 1 dan 2 jo. Pasal 6 UU ITE yang menentukan bahwa dokumen elektronik atau hasil cetaknya merupakan alat bukti yang sah dan dapat digunakan di muka persidangan, sepanjang informasi yang tercantum didalamnya dapat diakses, ditampilkan, dijamin keutuhannya, dan dapat dipertanggungjawabkan, sehingga menerangkan suatu keadaan. Disamping itu, dokumen elektronik kedudukannya disetarakan dengan dokumen yang dibuat di atas kertas, sebagaimana ditentukan dalam Penjelasan Umum UU ITE.

\section{Rekomendasi}

Berdasarkan keseluruhan uraian-uraian tersebut di atas, maka dapat diberikan saran sebagai berikut: Pertama, Diperlukan suatu upaya pemahaman kepada masyarakat, terkhusus bagi aparat penegak hukum tentang arti pentingnya prinsip pembuktian terkait dengan atas adanya perkembangan penggunakan dokumen elektronik; Kedua, Diperlukan adanya suatu upaya pemahaman kepada masyarakat, terkhusus bagi hakim, agar supaya mempunyai satu pemikiran yang sama tentang nilai kekuatan pembuktian alat bukti dokumen elektronik, setelah diberlakukannya UU ITE.

\section{DAFTAR PUSTAKA}

\section{Buku:}

Edmon Makarim, Bahan Seminar Nasional "Penggunaan Informasi/Dokumen Elektronik Sebagai Alat Bukti dalam Proses Litigasi", Fakultas Hukum Universitas Airlangga, Surabaya, Sabtu, 16 Juni 2012.

Fuady, Munir, 2001, Teori Hukum Pembuktian (Pidana dan Perdata), Bandung: Citra Aditya Bakti.

Hadjon, Philipus M. dan Tatiek Sri Djatmiati, 2005, Argumentasi Hukum, Cet. 1, Yogyakarta: Gadjah Mada University Press.

Jened, Rahmi, Perlindungan Merek dalam Transaksi E-commerce melalui Domain. Name, Laporan Penelitian, DIK Rutin Universitas Airlangga, Surabaya.
Mansur, Dikdik M. Arief dan Elisatris Gultom, 2009, Cyber Law: Aspek Hukum Teknologi Informasi, Bandung: Refika Aditama.

Marzuki, Peter Mahmud, 2005, Penelitian Hukum, cetakan I, Jakarta: Prenada Media.

Mertokusumo, Sudikno, 1998, Hukum Acara Perdata Indonesia, Edisi V, Yogyakarta: Liberty.

Muarif, Syamsul, Menunggu Lahirnya Cyber Law, http://www.cybernews.cbn.net.id.

Rachman, Minanoer, Ketua Pengadilan Negeri Tuban \& Hakim Pengadilan Tindak Pidana Korupsi pada Pengadilan Negeri Surabaya, Bahan Seminar Nasional "Penggunaan Informasi atau Dokumen Elektronik sebagai Alat Bukti dalam Proses Litigasi”, Fakultas Hukum Universitas Airlangga, Surabaya, Sabtu, 16 Juni 2012.

Soekanto, Soerjono, 1990, Pokok-pokok Sosiologi Hukum, Jakarta: Rajawali Pers.

Soesilo R., 1995, RBG/HIR dengan Penjelasan, Bogor: Politeia.

Sutantio, Retnowulan dan Iskandar Oeripkartawinata, 1997, Hukum Acara Perdata dalam Teori dan Praktek, Bandung: Alumni.

Ustadianto, Rieke, 2001, Framework E-commerce, Yogyakarta: Andi.

\section{Peraturan Perundang-undangan:}

Undang-Undang No. 14 Tahun 1985 tentang Mahkamah Agung.

Undang-Undang No. 5 Tahun 2004 tentang Perubahan atas Undang-Undang No. 14 Tahun 1985 tentang Mahkamah Agung.

Undang-Undang No. 48 Tahun 2009 tentang Kekuasaan Kehakiman.

Undang-Undang No. 49 Tahun 2009 tentang Perubahan Kedua atas Undang-Undang No. 2 tahun 1986 tentang Peradilan Umum.

Undang-Undang Republik Indonesia No. 11 Tahun 2008 tentang Informasi dan Transaksi Elektronik.

\section{Website:}

Kamus Online Merriem Websitester, www.m-w.com, diakses pada 5 Desember 2007.

Enda Nasution, http://blog.kenz.or.id/2006/02/09/ definisi-blog-menurut-orang-indonesia.html.

http://babasz-freedom.blogspot.com/2009/06/kasusprita-mulyasari-dengan-rs-omni.html, diakses pada tanggal 06 Oktober 2009. 